\title{
Problematika Teori Hukum, Konstruksi Hukum dan Kesadaran Sosial
}

\author{
Ilham Yuli Isdiyanto \\ Fakultas Hukum Universitas Ahmad Dahlan \\ Jl. Pramuka No. 42, Sidikan, Umbulharjo, Kota Yogyakarta, 55161 \\ 08112957721/ilham.isdiyanto@law.uad.ac.id
}

\begin{abstract}
This theoretical-normative study aims to determine the problematic use of legal theory and its impact on the construction of the law itself. This is very important because the construction of today's law has not created a social awareness of the law so that law enforcement becomes difficult. The discussion in this study raises several issues to be studied, such as; what is the dependencies pattern between law and social awareness? Then how to reconstruct them in the current of the Theory of Law? And the last is; what is the proper direction of legal creation? The results of this study conclude: First, the problem of alienation and distortion between law and society is just like an iceberg phenomenon because the main problem lies within the understanding theoritical of the law itself. Second, the relationship between law and social awareness is the dependence relationship, where the legal product must reflect social awareness so that the actualization of the law is accepted by society as its need. Third, discussing the correlation between law and society is not enough with normative thought (prescriptive), but also empirical (descriptive), so the theory of law plays a very important role to bring this multidisciplinary understanding back to normative thought that prescriptive. Fourth, the legal product which is not based on normative thought is very dangerous because it will be very liberal and far from social morality based on social values, thus there will be alienation and distortion between law and society, or in other words law does not reflect the social awareness.
\end{abstract}

Keywords: Problematic of Law Construction; Law Construction; Social Awareness

\begin{abstract}
Abstrak
Kajian teoritik-normatif ini bertujuan untuk mengetahui problematika penggunaan teori hukum dan dampaknya terhadap konstruksi hukum itu sendiri. Hal ini menjadi sangat penting karena konstruksi hukum hari ini belum menciptakan kesadaran sosial atas hukum sehingga penegakan hukum menjadi sulit. Pembahasan dalam kajian ini mengangkat beberapa persoalan untuk dikaji, diantaranya; bagaimana pola dependensi antara hukum dengan kesadaran sosial? Lalu bagaimana rekonstruksi keduanya dalam arus Teori Hukum? Terakhir adalah bagaimana arah penciptaan hukum yang seharusnya? Hasil kajian ini menyimpulkan: Pertama, persoalan alienasi dan distorsi hukum dan masyarakat adalah fenomena gunung es karena persoalan utamanya terletak di dalam pemahaman teoritik hukum itu sendiri. Kedua, hubungan hukum dengan kesadaran sosial adalah hubungan saling ketergantungan (dependen) dimana produk hukum harus mencerminkan kesadaran sosial sehingga aktualisasi hukum tersebut secara sadar diterima oleh masyarakat sebagai kebutuhannya (melembaga). Ketiga,
\end{abstract}


membicarakan korelasi antara hukum dan masyarakat tidak cukup dengan nalar normatif (preskriptif), tetapi juga empiris (deskriptif), sehingga teori hukum berperan sangat penting untuk membawa pemahaman multidisipliner ini kembali ke nalar normatif yang bersifat preskriptif. Keempat, produk hukum yang tidak didasari oleh nalar normatif sangat berbahaya karena akan sangat liberal dan jauh dari dasar moralitas sosial yang bertumpu pada nilai-nilai sosial, sehingga akan terjadi alienasi dan distorsi antara hukum dan masyarakat atau dengan kata lain hukum tidak mencerminkan kesadaran sosial.

\section{Kata Kunci: Problematika Konstruksi Hukum; Konstruksi Hukum; Kesadaran Sosial}

\section{A. PENDAHULUAN}

Hukum bukanlah suatu pemahaman yang tunggal, hukum di dalam hakekatnya sendiri sangatlah jamak dan tidak definitif. Bahkan hukum harus dicurigai sebagai bentuk ketidakkonsistenan dan paradoksalitas pemahaman yang tentunya menimbulkan pluralisme ide dan interprestasi terhadapnya. Namun, sebenarnya hal ini bukanlah kendala yang berarti, karena setidaknya hukum memiliki prinsip pokok yang melekat di dalam kehadirannya dimana ia menjadi 'cara dan tujuan untuk mewujudkan ketertiban sosial.

Dalam gagasan hukum yang normatif, ia adalah cermin dari masyarakat. Konstruksi berpikir ini kemudian menempatkan posisi hukum yang selalu menjadi bayang-bayang masyarakat. Hukum dinamis sekaligus statis, ataupun statis sekaligus dinamis. Artinya, hukum seakan bergerak layaknya masyarakat itu sendiri yang bergerak, namun sebenarnya ia diam atau setidaknya terlihat diam, begitu juga sebaliknya hukum terlihat diam namun pada dasarnya ia bergerak mengikuti gerak masyarakat.

Aspek dinamis-statis ini mengisyaratkan pada satu bentuk persinggungan antara hukum sebagai wilayah normatif dengan masyarakat sebagai wilayah empiris. Keduanya saling terrefleksikan lewat apa yang disebut dalam bahasa hukum sebagai korelasi abadi antara das sollen dan das sein.

Namun, korelasi antara sollen dan sein sering ditanggapi terlalu dangkal, sehingga sollen dalam pengertian buruknya sering diartikan sebagai produk penguasa yakni undang-undang yang dibuat oleh otoritas resmi dan sein dipahami sebagai gejala sosial yang selalu reaktif terhadap isu-isu sosial. Dasar pemahaman seperti ini tentunya memisahkan korelasi sollen dan sein, sehingga yang muncul bukanlah hukum yang muncul sebagai konstruksi reflektif sosiologis, melainkan terbagi atas kubu ekstrim positivistik (legisme) dan sosiologis.

Sollen harus dikembalikan pemahamannya sebagai "keharusan" dalam perspektif moralis, yakni sebuah keharusan yang muncul dari refleksi sosial. Sedangkan sein harus dipahami sebagai respon terhadap sollen. Di sini, wilayah sein bisa disebut sebagai wilayah "kesadaran atas sollen" karena itu merupakan aktualisasi daripada sollen. Kesadaran atas sollen mengandung arti bahwa hukum 
tersebut telah mewujudkan sebuah ketertiban sosial atau dalam wacana sosiologis disebut dengan istilah "hukum tersebut telah melembaga". Hukum yang telah melembaga tersebut mengisyaratkan masyarakat yang sadar atas hukum.

Memahami korelasi hukum dengan kesadaran sosial bukanlah suatu bentuk pemikiran yang tunggal, melainkan jamak. Sehingga, teknik berpikir yang plural ini merupakan suatu bentuk metode multidisipliner dimana wilayah kental normatif diolah bersama-sama dengan keilmuan empiris seperti sosiologis, politik dan antropologis. Terakhir akan dikonstruksikan aspek-aspek preskriptif dari olahan tersebut.

Persoalan hukum dan kesadaran sosial ini menjadi sangat penting sebagai upaya pemecahan terhadap problematik penciptaan dan penegakan hukum yang ternyata keluar dari "pakem" pokoknya - bahkan diluar kendali normatif. Untuk melihat persoalan ini dapat dilihat dari fenomena ketidakberlakuan hukum atau ketidakmengertian masyarakat terhadap hukum, yakni selalu terjadi alienasi dan distrosi antara hukum dengan masyarakat. Persoalan bukan hanya dalam perdebatan di wilayah aktualisasi (penegakan) hukum, melainkan di dalam pokok teoritiknya. Kelalaian teoritik akan berujung pada hukum yang tidak berkonsep, hukum yang tidak memiliki jiwa, dan bahkan terkesan arogan yang sering dinilai otoriter.

Efek domino dari problem ini yakni hukum tidak menjadi bagian dari kesadaran subtantif (kesadaran hukum) didalam dinamika sosial, melainkan hanya formalitas Negara dalam mewujudkan ketertiban dan stabilitas nasional. Beberapa penelitian - terutama sosiologi hukum - telah memberikan gambaran bahwa kesadaran hukum masih lemah. Gambaran yang lebih khusus bisa diambil contoh penelitian tingginya tindak pidana narkotika di Sulawesi Tengah sangat dipengaruhi kesadaran hukum yang rendah (Rampadio, 2015: 69), kesadaran hukum berlalu lintas di Kepulauan Meranti yang minim (Ruba'i, 2015:14), kesadaran hukum tindak pidana korupsi yang sangat tinggi sebagaimana laporan KPK tahun 2016 dan 2017 (Laporan KPK 2016 dan Laporan KPK 2017; https://www.kpk.go.id/id/publikasi/laporan-tahunan/), dan tingginya jumlah perkara di Mahkamah Agung seperti pada periode Januari-Oktober 2016 mencapai 16.012 dan sampai Oktober 2017 berhasil diputus 13.394 perkara (https://kepaniteraan.mahkamahagung.go.id/index.php/kegiatan/ 1543-periodejanuari-oktober-2017-91-16-perkara-diputus-ma-kurang-dari-3-bulan).

Banyaknya pelanggaran dan perkara-perkara tersebut diatas memang merupakan sebagian kecil dari fenomena gunung es di Indonesia terkait problematika hukum dan kesadaran masyarakat atasnya. Kesadaran atas hukum tidak hanya mengetahui hukum, melainkan mengerti dan memahami konsekuensikonsekuensi atasnya sehingga pelanggaran atasnya semakin tereduksi. Dari sini, yang ingin dipersoalkan bukan bagaimana cara agar masyarkat sadar hukum dan 
menjadi bagian dari kesadaran sosialnya, melainkan bagaimana problem hukum itu sendiri sejak dalam wilayah konstruksinya, sehingga hukum tidak hanya persoalan legalitasnya secara formal, melainkan validitasnya didalam masyarakat secara material juga perlu untuk dipertanggungjawabkan. Konstruksi hukum yang tidak hanya terpaku pada legal-formal menjadi wacana yang sangat penting, arahnya adalah membangun konstruksi hukum yang sesuai dengan kesadaran sosial masyarakat sehingga nantinya hukum lebih mudah diterima dan dipahami oleh masyarakat atau terciptanya kesadaran hukum yang subtantif.

Kajian ini membahas persoalan teoritik secara multidisipliner. Wacana dan analisis teoritik sendiri hingga saat ini masih sangat jarang, para pemikir hukum sepertinya lebih suka untuk berpikir teknokratis-pragmatik daripada teoritik. Lemahnya wacana-wacana teoritik secara orisinil inilah yang menjadi faktor mengapa ilmuwan hukum sangat jarang, padahal begitu banyak persoalan teoritik yang perlu dipecahkan dan dicari jalan keluarnya. Di Indonesia pun hingga saat ini terjadi absurditas teoritik (kebingungan penggunaan teori) yang menjadi dasar dari sistem hukum nasional. Kajian ini akan memberikan suatu gambaran peta problematika teoritik hukum, terutama untuk mengurai pola dependensi antara dasar pemikiran normatif hukum dengan kesadaran sosial dan efek domino cara pandang terhadap hukum yang sangat berdampak pada produk hukum serta kesadaran masyarakat terhadapnya.

Permasalahan pokok dalam kajian ini adalah bagaimana mengetahui pola dependensi antara hukum dengan kesadaran sosial? Lalu bagaimana rekonstruksi keduanya dalam arus Teori Hukum? Terakhir adalah bagaimana arah penciptaan hukum yang seharusnya?

\section{B. PEMBAHASAN}

\section{Dinamika Sollen dan Sein}

Salah satu pertanyaan besar adalah apakah hukum itu otonom? Pernyataan hukum otonom perlu dicurigai sebagai upaya untuk mempolitisir hukum secara sepihak oleh penguasa. Hans Kelsen dengan teori norma berjenjang hingga jenjang tertinggi disebutnya sebagai Grundnorm membuktikan bahwa hukum bukanlah sebuah dunia terpencil yang terbebas dari pengaruh apapun. Bahkan dengan tegas ia menyatakan jika sebuah tatanan hukum tak lebih dari sistem norma (Kelsen, 2011: 159). Sebuah sistem bagaimanapun juga adalah korelasi dari berbagai unsur yang saling bertemu dan membentuk suatu pola secara keseluruhan (Amirin, 1989: 1). Sehingga, sistem di sini tidaklah mungkin dilihat secara statis, melainkan dinamis (Kelsen, 2011: 163). Kesadaran bahwa tatanan hukum merupakan sistem semakin terasa, oleh karenanya pemahaman sistem hukum atau norma tidak dipahami lagi sebagai sebuah keadaan, bahkan sebagai metode (Amirin, 1989: 3-4). Setidaknya, menurut Lili Rasjidi dan I.B. Wyasa Putra (2003: 4) menyatakan urgensi penggunaan metode sistem terhadap hukum karena tiga faktor pokok: 
a. Pendekatan sistem merupakan metode semi-metafisika yaitu selain memiliki kemampuan untuk menggambarkan keutuhan karakteristik objek, juga memiliki kemampuan untuk melakukan analisis terhadap setiap komponen objek;

b. Keberhubungan suatu objek secara internal dan eksternal;

c. Pendekatan ini lebih representatif untuk ontologi, epistimologi, dan aksiologi ilmu pengetahuan, sesuai dengan karakteristik esensialnya.

Pertanyaan selanjutnya adalah, apakah korelasi antara das Sollen dan das Sein termasuk korelasi sistem atau terpisah? Karena perlu diperhatikan bahwa keduanya berada dalam dua alam yang berbeda. Sollen berada dalam alam "idea" hasil dari akumulasi moralis, sedangkan sein berada dalam alam "realitas" yang seharusnya menjadi penjelmaan langsung dari sollen.

Dinamika antara sollen dan sein merupakan keterkaitan antara idea-normatif dengan realitas keberlakuan norma. Hal ini kemudian menimbulkan pertanyaan, apakah sollen merupakan penerjemahan dari cita-cita ideal hukum atau tujuan hukum? Sebuah validitas dari sollen adalah sejauhmana keberlakuannya di dalam masyarakat (sein). Hans Kelsen sendiri secara tegas menyatakan bahwa validitas dari suatu tatanan hukum sangat bergantung pada realitas atau keefektifitasannya (Kelsen, 2011: 174). Namun, persoalannya adalah tujuan dari hukum sendiri yang merupakan sesuatu yang ideal sangatlah abstrak dan tidak operasional (Marzuki, 2013: 88). Jika mengacu pada pemikiran Radbruch maka idealitas tersebut terbagi menjadi tiga; supremasi hukum, kemanfaatan, dan keadilan. Namun, aktualisasi ketiganya tidaklah bisa komulatif, melainkan sebatas fakultatif. Terhadap konsep tersebut Meuwissen bahkan memberikan kritik bahwa pemikirannya tidaklah didasari pada pemikiran yang mendalam (kontemplatif), tetapi sebatas sebuah kebetulan semata karena korelasi ketiganya berubah-ubah dan tidak memuaskan (Meuwissen, 2007: 20).

Sollen menurut penulis adalah kristalisasi dari tujuan-tujuan hukum yang abstrak, ia muncul dari akumulasi moralis refleksi sosial, bukan hanya sebatas penciptaan tanpa makna. Pembuatan aturan bahwa membunuh dapat diancam dengan sanksi 20 tahun penjara muncul dari dasar pemahaman (moral) bahwa membunuh itu dilarang karena akan memberikan dampak sosial yang kurang baik, sehingga masyarakat yang nyaman dan ideal adalah yang di dalamnya tidak ada pembunuhan, oleh karenanya muncullah suatu bentuk pemahaman ideal tentang bentuk pengaturan beserta sanksinya untuk membuat orang takut dan mencegah untuk membunuh. Di sini, norma tersebut (sollen) adalah perwujudan dari kesadaran sosial yang muncul dari refleksi terhadap keadaan yang sebenarnya (sein). 
Sollen tidak bisa dipisahkan dari sein karena tidak mungkin bisa disebut sebagai ide moralis atas hukum (sollen) tanpa didasari dari sebuah refleksi atas dinamika empiris sosial (sein). Oleh karenanya, penggambaran atas korelasi keduanya adalah sebuah hubungan mono-dualis, karena berbeda namun harus dilihat dalam keterkaitan mutlak.

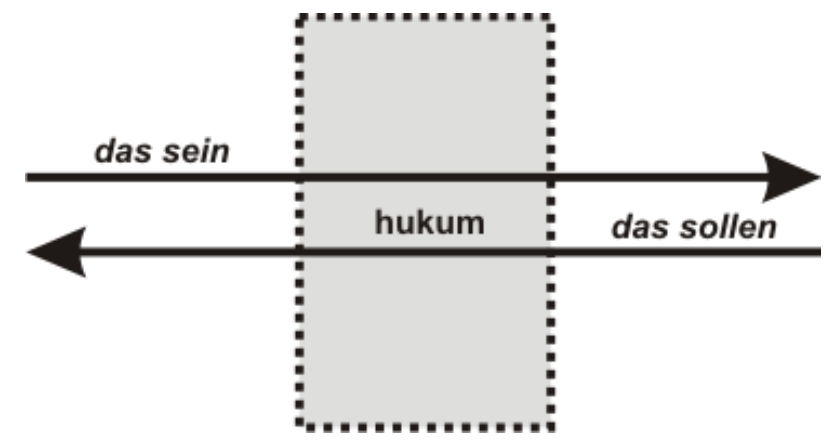

Gambar 1. Mono-dualis das sollen dan das sein dalam hukum

Semangat dari hukum pada dasarnya diartikan sebagai jiwa dari sein, sehingga sebuah penciptaan hukum baik oleh institusi formal ataupun lembaga organis di dalam masyarakat harus memperhatikan aspek ini. Tentunya, sebuah sollen yang tidak di didasari sein akan berubah menjadi hukum otoriter dengan semangat subyektifisme murni dan sebatas pada pragmatisme kekuasaan, tanpa memperhatikan validitas atasnya. Sebagaimana dinyatakan oleh Hans Kelsen bahwa efektifitas atas hukum sangat bergantung dari validitasnya, dan validitas sangat bergantung dengan realitasnya (Kelsen, 2011: 174-176). Jika hal ini diabaikan maka hukum hanya sebatas menjadi alat kekuasaan sebagaimana yang terjadi pada negara Fasis atau Komunis.

\section{Hukum Bukan Gejala Sosial}

Hukum yang merupakan norma-norma memang dijiwai oleh sein sebagai semangat dari cita-cita hukum tersebut, atau biasa disebut idea-hukum. Namun, perlu diperhatikan satu hal bahwa konstruksi produk norma tersebut bukanlah sebagai representatif langsung (direct representative) dari sein. Perlu dipahamkan bahwa sollen merupakan hasil refleksi atas sein, bukan reaktif atas sein. Konotasi keduanya sangatlah jauh berbeda.

Tentu hal ini akan sangat berbeda dengan pandangan dari para penganut Sosiologi Hukum yang mengidentikkan hukum sebagai gejala sosial, seperti yang dinyatakan oleh Lawrence M. Friedman dalam bukunya Sistem Hukum Perspektif Ilmu Sosial (Friedman, 2009: 4):

"Jadi, tekanan untuk menciptakan sebuah hukum baru, atau mempertahankan hukum lama, muncul dari sikap dan perasaan yang menampilkan tuntutan kepada sebuah kelompok atau individu. Yang menjadi proposisi dasar dalam hakikat sistem hukum adalah bahwa tuntutan-tuntutan ini menentukan 
kandungan isinya. Artinya, hukum bukan merupakan suatu kekuatan kokoh yang idependen melainkan merupakan respon atas tekanan luar dengan cara tertentu yang mencerminkan kehendak dan kekuatan-kekuatan sosial yang mengerahkan tekanan tersebutt."

Dasar berpikir Friedman tersebut adalah hukum bertolak secara langsung dari reaktif sosial, sehingga hukum tak lain adalah gejala sosial. Ia memungkinkan untuk segera berganti jika ada kontroversi sosial dan reaktif terhadap dinamika atasnya.

Jika hukum adalah produk dari gejala sosial akibat kontroversi didalamnya maka ia tidak mempunyai suatu pandangan yang tetap terhadapnya, karena unsur reaktif ini tentu lebih pada pola pandangan pragmatisme hukum secara subyektif. Terhadap hal ini, Hazairin secara tegas menyatakan penolakannya, ia menyatakan (Hazairin, 1974: 58):

"Paham yang memandang hukum itu semata-mata sebagai gejala sosial bukanlah paham yang dianut dalam negara Panca Sila, malahan juga tidak dianut oleh negara Komunis dan hanya dianut oleh negara demokrasi liberal, di mana adu tenaga dan kekuatan, pertentangan antara si kaya dan si miskin, pertentangan antara kapital dan labor (kaum buruh...)"

Hukum sebagai gejala sosial memang sering dikumandangkan pagi penganut sosiologi hukum. Tentunya di sini hukum tak perlu lagi berpijak pada Ground Norm ala Hans Kelsen ataupun Staatfundamentalnorm ala Hans Nawiasky, tetapi hukum lebih ditekankan sebagai akibat dari kontroversi sosial yang reaktif sehingga kelompok mana yang menang maka ialah yang menentukan kemana arah hukum selanjutnya.

Dalam perkembangannya, hukum sebagai gejala sosial kemudian dilegitimasi oleh pemahaman-pemahaman yang bersifat politis atau sosiologis, yakni mencampuradukkan aspek empiris sebagai determin atau variabel terhadap aspek normatif secara langsung. Nonet dan Selznick adalah yang paling menonjol dalam hal ini, dengan konsep hukum responsif mereka mencoba mendobrak dikotomi antara sekat empiris dan normatif, bahkan memandang aspek normatif secara empiris lewat ilmu sosial. Konsep fusion yang ditawarkan oleh Nonet dan Selznick ini sebagaimana mereka nyatakan (Nonet dan Selznick, 2015: 4):

"Agar ilmu hukum lebih relevan dan lebih hidup, harus ada reintegrasi antara teori hukum, teori politik, dan teori sosial. Sebagai suatu langkah ke arah itu, kami telah mencoba untuk menyusun kembali isu-isu dalam ilmu hukum dalam suatu perspektif ilmu sosial".

Karya Nonet dan Selznick ini kemudian menjadi dasar yang kuat dalam perkembangan sosiologi hukum, sehingga yang terjadi bukanlah normative heavy terhadap pembacaan hukum melainkan politic and sociology heavy.

Hukum sebagai gejala sosial memang sangat kuat dari pengaruh pemahaman politik dan sosiologi, sehingga sikap pragmatisme yang menjadi dasar atasnya. 
Namun sebenarnya, setiap aspek teoritik kelimuan memiliki sudut pandangnya masing-masing. Metode berpikir yang fusion akan menimbulkan kerancuan asumsi dan kegagalan logika ilmiah, sehingga yang paling memungkinkan adalah model paradigma federasi keilmuan dengan metode multidisipliner. Jujun S. Suriasumantri dengan tegas menyatakan bahwa sebuah ilmu pada dasarnya bersifat otonom dalam bidang kajiannya masing-masing dan berkesatuan dalam suatu pendekatan multidisipliner, bukan "fusi" dengan menggabungkan asumsi yang kacau. Sebuah asumsi haruslah relevan dengan bidang dan tujuan pengkajian disiplin keilmuan dan asumsi harus disimpulkan dari keadaan sebagaimana adanya bukan sebagaimana seharusnya. Menggunakan asumsi yang berbeda maka berbeda pula konsep pemikiran yang digunakan (Suriasumantri, 2010: 89-90).

Salah satu contohnya adalah saat fusion Politik Hukum disebut sebagai atau bagian dari Ilmu Hukum, maka muncul tiga asumsi dasar atasnya (Mahfud MD, 2012: 10): hukum determin politik, politik determin hukum, dan atau keduanya saling deterministik. Saat menyatakan hukum determin politik, maka di sini adalah ruang normatif (Sollen), namun saat berbicara politik determin hukum maka di sini adalah ruang empiris (Sein), sehingga kedua asumsi tersebut pada dasarnya bertentangan satu sama lain. Ranah keilmuan normatif (normologis) tidak bisa dicampuradukkan dengan ranah keilmuan empiris (Sidharta, 2009: 111-113). Oleh karena kerancuan asumsi yang kontradiktif ini maka keduanya tidak bisa disatukan (fusion) namun cara pandang atas keduannya dapat digunakan lewat pendekatan multidisipliner (federasi keilmuan). Dari sini sangat jelas bahwa Politik Hukum tidak bisa dimasukkan kedalam ranah Ilmu Hukum yang normatif, melainkan ilmu sosiologis yang empiris.

Akan sangat berbahaya jika asumsi ini dibenarkan sebagai bagian dari Ilmu Hukum, sehingga akan muncul sebuah konsentrasi berpikir oleh para sarjana hukum bahwa hukum merupakan produk politik, dan pembentukan hukum tak lain hanya sebatas pada aspek konfigurasi politik semata. Secara perlahan namun pasti, pemahaman ini akan dapat mengubah keadaan negara yang Rechstaat (Negara Hukum) menjadi Machstaat (Negara Kekuasaan), karena hukum dikendalikan oleh politik peraduan kekuasaan, namun bukan dalam pemahaman otoritarian melainkan kontroversi atau gejala sosial. Di dalam negara demokrasi, pertentangan antar kekuatan yang bersifat politis lebih terasa karena melibatkan para elit oligarki dan organisasi-organisasi sosial yang berkepentingan dengan melakukan tuntutantuntutannya dan melakukan mobilisasi untuk menciptakan kontroversi sosial

\section{Gejala Sosial dan Kesadaran Sosial}

Pada dasarnya, pemahaman tentang kesadaran sosial adalah masuk dalam lingkup empiris, namun tidak menutup kemungkinan dalam beberapa hal tertentu hal itu juga menjadi bagian dari pemahaman lingkup normatif. Saat kesadaran sosial akan hukum dilihat sebagai hasil dari kinerja hukum, sehingga perlu diketahui variabel-variabel bebas dan variabel terpengaruhnya maka hal yang seperti itu 
masuk di dalam lingkup pemahaman empiris. Sedangkan jika dalam hal kesadaran sosial dikaitkan sebagai bagian dari kesadaran moralis dalam pembentukan hukum atau norma sehingga memiliki jiwa dan semangat didalamnya sesuai dengan kesadaran masyarakat maka lingkup tersebut masuk dalam ranah normatif.

Kesadaran sosial tidak selalu sama dengan gejala sosial, dalam waktu tertentu sering keduanya identik -terutama dalam pemahaman lingkup empiris. Kesadaran sosial sebagai produk hukum berarti penciptaan norma sesuai dengan kehendak nilai-nilai masyarakat dan kebutuhan didalamnya untuk mewujudkan idea-hukum masyarakat yang bertatanan dan tertib, sehingga setelah norma tersebut mencapai bentuk realistisnya baik tertulis ataupun tidak, maka kepatuhan terhadapnya adalah kepatuhan murni sesuai dengan kebutuhan masyarakat itu sendiri. Inilah saat yang paling menentukan, dari sudut pandang empiris akan muncul pertanyaan, sudahkah norma atau hukum tersebut membudaya atau melembaga? Suatu norma dikatakan melembaga dan membudaya apabila warga masyarakat -baik pribadi maupun kelompok- mengetahui, menghargai, memahami, dan mentaati (patuh) terhadap norma-norma tersebut (Soekanto dan Abdullah, 1980: 285). Mengetahui saja tidaklah cukup, seseorang perlu memahami dan menghargai hukum atau norma tersebut sehingga bisa dikatakan bahwa aktualisasi terhadapnya sudah benar-benar selaras dengan kesadaran sosial, yakni hukum sudah masuk ke dalam sistem kultural mereka (budaya hukum).

Kebudayaan sebagai hasil dari pemikiran kolektif dan komunal tentu sangatlah normatif, oleh karenanya korelasi kebudayaan dengan hukum tidak bisa dihindari. Hukum merupakan anak kandung dari kebudayaan, oleh karena itu validitas dan efektifitas hukum sangat dipengaruhi oleh kebudayaannya sebagai wujud dari kesadaran sosialnya. Sistem kebudayaan dengan nilai-nilai normatifnya akan sangat membutuhkan hukum untuk tetap lestari dimana hukum memiliki kekuasaan untuk memaksa setiap orang mematuhi norma sosial di dalam sistem kebudayaan tersebut (Ihromi (Peny.), 1984: 6).

Dapat diinsyafi di sini bahwa peran budaya sangat menentukan sebuah validitas hukum, bisa dikatakan sebuah hukum atau norma akan kehilangan sisi normatifnya jika ia bertentangan atau bertolak dengan budaya. Budaya adalah kesadaran sosial yang sudah mencapai tarafnya, unsur pembentuk yang paling terasa adalah akumulasi nilai-nilai yang telah berjalan dan berproses dari tahuntahun sebelumnya. Jelas ini bukan sebagai salah satu bentuk gejala sosial yang hanya membutuhkan kontroversi sosial didalamnya. Akan sangat sulit dibayangkan jika sebuah norma yang terbentuk dari gejala sosial dan ternyata didalamnya terdapat kontroversi kultural yakni adanya penetrasi budaya asing terhadap budaya lokal setempat. Jelas produk hukum yang dihasilkan tidak bisa dipahami dan dihargai oleh masyarakat setempat sehingga terjadi alienasi dan distorsi antara hukum dan masyarakat. 
Dari sinilah kemudian konsep budaya hukum muncul sebagai bagian dari sebuah sistem hukum. Budaya hukum pada dasarnya merupakan konkretisasi nilainilai yang dianut masyarakat yang berhubungan erat dengan pola pikir dan kebatinan mereka (Tohir, 2011:106). Konsep budaya hukum sendiri dalam perkembangannya digunakan sebagai dasar pemahaman sosiologi hukum ala Friedman dengan sistem hukumnya, sejarah hukum ala Savigny dengan volkgeist (jiwa rakyat), maupun Eugen Ehrlich dengan living law-nya.

Secara antropologi, penciptaan norma tertentu memang bisa mengarahkan perubahan nilai budaya (Ihromi (Peny.), 1984: 11), seperti konsep Marxisme atau gaya Roscoe Pound dengan asumsi 'hukum sebagai alat perubahan sosial (law as a tool of social engineering) yang oleh Mochtar Kusumaatmadja diartikan hukum sebagai sarana pembangunan. Percobaan hukum sebagai "alat" atau "sarana" ini kemudian dengan tegas ditentang oleh M. Koesnoe karena beberapa hal, yakni; pertama, ajaran fungsional tentang hukum sebagai "alat" atau "sarana" perubahan sosial disangkal keampuhannya oleh para Antropologi Hukum (Koesnoe, 2002: 75), kedua, pengertian atas "law" dalam pandangan Pound masih sangat ambigu dan Sociology Heavy dan ketiga, pandangan tersebut tidak sesuai dengan pandangan bangsa Indonesia (Koesnoe, 2002: 74-77).

Pandangan Koesnoe tersebut menekankan pada satu paham bahwa pembentukan norma harus didasari pada aspek-aspek normatif, bukan hanya lewat aspek empiris. Norma pada dasarnya adalah "idea" yakni lingkup sollen, sehingga ia hanya bisa diterjemahkan ke ranah empiris (sein) lewat aktualisasi sollen sebagai daya preskriptifnya. Standar normatif ini adalah pakem keilmuan hukum yang didasarkan pada kesadaran sosial atau refleksi sosial (kebudayaan), bukan gejala sosial (reaksioner).

\section{Penciptaan Hukum yang Seharusnya}

Pembicaraan terhadap model penciptaan hukum di sini bukan melihat secara khusus pada formal-legalitas negara, tetapi melainkan pada prinsip dasar yang seharusnya dilewati dalam proses penciptaan hukum tersebut. Istilah "penciptaan" di sini bukanlah merujuk pada sesuatu yang baru, tetapi merujuk pada aspek produk hukum oleh masyarakat tradisional (Adat) ataupun oleh negara sebagai lembaga kekuasaan formal modern.

Hukum dalam pengertian preskriptifnya adalah sebuah ide, yakni hasil dari refleksi sosial yang berupa nilai-nilai. Sifat nilai ini sangatlah abstrak dan bergantung tidak hanya pada rasionalisasi pikiran, tetapi juga transendental yang berdasarkan nurani. Secara umum nilai ini yang mengatur pemilihan benar dan salah, baik dan buruk, kejahatan dan kebajikan, atau mana yang dikehendaki ataupun ditolak (Mertokusumo, 2011: 12). Nilai-nilai ini yang kemudian dikristalisasi menjadi sebuah asas-asas hukum, dan asas ini tetap mempertahankan nilai abstraknya. Dari asas-asas hukum ini kemudian dikonkretkan lagi menjadi 
sebuah norma ataupun kaedah hukum (tertulis dan tidak tertulis). Korelasi ketiganya sangat menentukan sebuah proses penciptaan hukum, sehingga sebuah norma yang tidak bisa ditelusuri asas atau nilainya sudah pasti bukanlah hukum dalam pemahaman normatif.

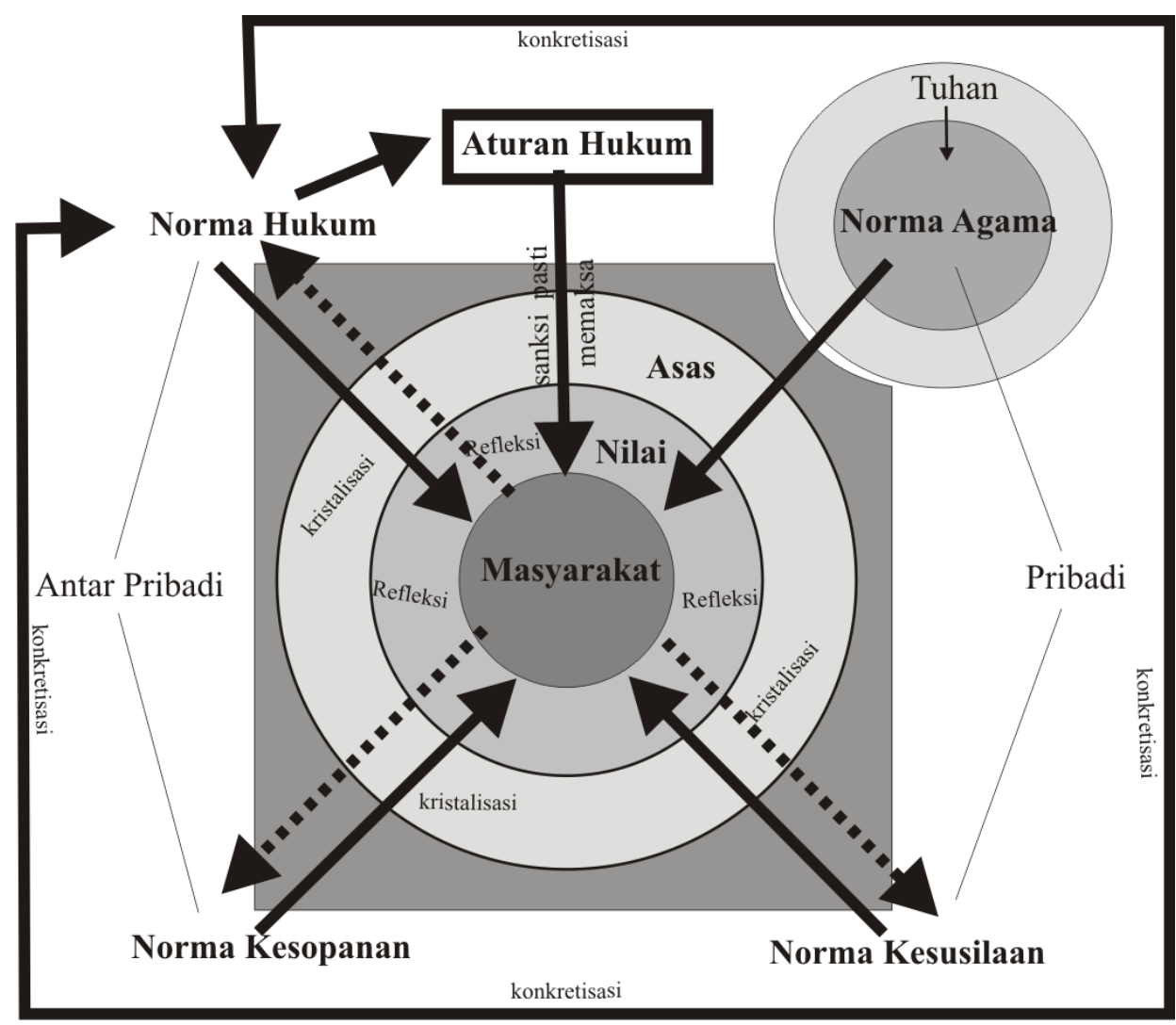

Gambar 2. Proses Reflektif dari Nilai, Asas, Norma, Hingga Norma Hukum (Isdiyanto, 2015:55)

Fenomena terhadap teori ketatanegaraan yang melakukan "pemisahan" (separation) atau "pembagian" (distribution) kekuasaan dan wewenang yakni; legislatif, yudikatif, dan eksekutif sering tidak dibarengi dengan konstruksi penciptaan hukum yang sesuai. Legislatif perlu dicurigai, apakah norma yang dibuatnya sudah mengakomodir nilai dan asas hukum di masyarakat. Paling tidak hal ini perlu diragukan, karena masih secara umum -apalagi Indonesia- saat masyarakat ditanyakan tentang seperti apa sistem hukum bekerja maka mereka cenderung untuk menghindar dan tidak memahami. Tidak mengherankan kemudian jika implementasi hukum selalu mendapat rintangan dan terkesan dipaksakan dengan slogan fiksi hukum tanpa dipahami hukum apa itu. Hukum memang memiliki sifat memaksa, namun itu (memaksa) bukanlah yang hakiki dan tidak selalu identik sehingga ia bukanlah suatu hal yang harus selalu dipaksakan (Kan dan Beekhuis, 1955: 14-15) jika hal ini diingkari maka hukum nantinya malah terkesan otoriter dan arogan. 
Alasan apakah yang paling cocok untuk pembuatan sebuah norma; kebutuhan, kepentingan, atau tuntutan? Untuk memilih diantara ketiganya sangatlah sulit, karena situasi dan kondisi akan sangat menentukan produk hukum yang dihasilkan. Kita lihat, Indonesia dengan terpaksa menggunakan hukum sisa kolonial untuk mengisi kekosongan hukum, hasilnya hal itu lambat laun diterima dengan sadar dan diakui secara natural. Walau masih membutuhkan penyesuaian tentu hal itu wajar sebagai sisi dinamis hukum. Hal menarik juga bisa lihat di Jepang bagaimana hukum Barat (asing) diadopsi secara sadar dan digunakan untuk menentang kekuasaan Barat (A.A.G. Peters dan Siswosoebroto (Ed.), 1988: 10). Fenomena di wilayah Asia ini memang menarik, karena mayoritas negara-negaranya mengadopsi hukum Barat sebagai suatu tuntutan modernitas, tentunya tidak secara menyeluruh. Jepang sendiri masih memberikan tempat yang sangat terhormat bagi nilai-nilai hukum lokalnya. Namun, di beberapa negara seperti Indonesia kedudukan hukum lokal atau Adat masih subordinat dari hukum nasional. Kedudukan Adat sebagai subordinat dari hukum nasional ini sebagaimana dikemukakan oleh Hart (2009: 71):

"Adat-istiadat dalam dunia modern tidak termasuk 'sumber' hukum yang terlalu penting. Biasanya adat menjadi sumber hukum yang bersifat bawahan (subordinat). Dalam pengertian bahwa badan legislatif melalui undang-undang menghilangkan status hukum dari sebuah peraturan adat...".

Hal ini berimplikasi dominasi negara yang sangat kuat dan bisa serta merta melakukan intervensi bahkan arogansi terhadap eksistensi hukum lokal atau Adat. Persoalan akan berlanjut karena hukum lokal atau Adat ini yang ternyata sesuai dengan kesadaran dan sistem pranata sosial setempat, sehingga penetrasi hukum nasional terhadap hukum lokal atau Adat perlu dipertanyakan legitimasi normatifnya.

Beberapa wilayah seperti Papua atau Kalimantan, perang antar suku tidak bisa diselesaikan dengan menggunakan hukum nasional. Tetap saja ia harus diselesaikan secara 'Adat' yang dinilai paling baik mewujudkan aspek 'keseimbangan kosmis' dan tentu saja dinggap paling adil. Setidaknya, validitas atas hukum tersebut (hukum lokal) telah terbukti dengan efektifitasnya.

Hukum lokal atau Adat harus dilihat sebagai contoh penciptaan norma yang paling mendekati sempurna karena kepatuhan terhadapnya adalah bersumber dari kesadaran komunal, setiap norma diletakkan dalam wilayah yang abstrak dan diimplementasikan kedalam persoalan konkret dengan upaya budaya diskresi yang didasarkan pada metode berpikir yang kuat. Namun, moralitas dijunjung sebagai sifat yang paling menonjol dan diakui oleh seluruh masyarakat. Lembaga legislatif yang akan membuat norma baru seharusnya membuat daftar panjang dan riset terhadap aspek kemasyarakatan, terutama terkait bagaimana konstruksi nilai dan asasnya, dan reaksi sosial atas implementasinya. 
Hukum telah kehilangan aspek preskriptifnya karena tidak didasarkan pada refleksi sein, tetapi lebih pragmatis lewat lobi-lobi politik. Seperti yang dikatakan oleh Mahfud MD dalam studi empiris lewat disertasinya, begitu jelas terlihat bahwa konfigurasi politik sangat mempengaruhi produk hukum (Mahfud, 2012: 22). Satu kemungkinan yang paling kuat adalah, pemikiran lembaga legislatif sangat politis daripada normatif, dan eksistensinya sebagai hukum memang perlu diragukan. Di sini berarti penciptaan norma oleh legislatf tidak didasarkan pada pemahaman ilmu hukum, tetapi sebatas ilmu politik, sehingga hukum yang seperti itu bukanlah hukum dalam pengertian Sollen, tetapi sebatas pada kebijakan politis. Oleh karenanya, kekuatan yang paling menonjol bukanlah aspek tuntutan sosiologis terhadap hukum untuk menciptakan sebuah ketertiban dan tatanan sosial, tetapi lebih terasa dominasi negara lewat hukum sebagai alat legitimasi kekuasaan untuk dapat memaksa kehendaknya terhadap masyarakat secara umum. Hukum tak lagi muncul dengan sifat transendental dan metafisisnya sehingga pendahuluan moralitas diutamakan, tetapi hukum muncul sebagai kekuatan politis yang menjemukkan yang dilegitimasi oleh sifatnya yang memaksa dan lebih terkesan dipaksakan.

Efek buruknya adalah, masyarakat akan terlalu percaya jika hukum telah dipolitisir -dalam pemahaman negatif- bahkan sejak diciptakannya. Satjipto Rahardjo sendiri sebagai pioner Sosiologi Hukum menyatakan bahwa hukum itu sendiri sering bersifat kriminogen, yakni membuat peluang bagi tindak kejahatan (Rahardjo, 2007: 14). Pembacaan-pembacaan sosiologis seperti diatas adalah kritik bahwa konstruksi hukum yang tidak didasari dengan dasar pemahaman teoritik yang benar (konstruksi normatif) menghasilkan hukum yang tidak sesuai dengan semangat dan nilai-nilai yang ada di masyarakat. Walaupun dalam hal ini tidak ditujukan pada keseluruhan produk hukum yang dihasilkan, namun setidaknya sudah banyak produk hukum yang tidak sesuai dan peluang untuk hal itu selalu ada di setiap produk hukum lainnya.

Alienasi dan distorsi antara hukum dan masyarakat yang tinggi membawa akibat-akibat yang buruk, tentu hal ini sangat berpengaruh terhadap penegakan hukum dalam skala nasional. Persoalan bahkan kian diperburuk dengan arogansi kekuasaan yang terlalu memaksakan hukum untuk dijalankan, dengan berpedoman pada asas legalitas maka semua seakan legal untuk dilancarkan dengan mengatasnamakan hukum. Pengaruh pendidikan teknokratis mendorong pemahaman hukum sebatas pada teks-teks kosong tanpa makna, sangat tekstual dan miskin logika, terutama saat dasar-dasar pemahaman teori dan filsafat hukum tidak dipahami dengan baik oleh para penegak hukum.

\section{KESIMPULAN DAN SARAN}

Tujuan dan semangat hukum yang paling universal adalah menciptakan tatanan masyarakat yang tertib, aman, nyaman dan seimbang. Oleh karenanya, hukum harus berasal dari nilai-nilai yang ada di dalam masyarakat itu sendiri yang 
diproses lewat proses refleksi normatif yang terbuka dan sistemik. Hukum yang didalamnya tidak terkandung nilai-nilai sosial kemasyarakatan tentu sudah kehilangan eksistensi normatifnya dan yang lebih parah adalah eksistensi keberlakuannya sebagai hukum yang notabene adalah akumulasi nilai-nilai sosial.

Hukum yang merupakan refleksi sosiologis sering salah dimaknai sebagai gejala sosial yang tendensius pada penciptaan hukum lewat kontroversi sosial. Anggapan yang paling mencolok adalah hukum merupakan hasil dari adu kekuatan di dalam dinamika sosial sehingga yang muncul adalah siapa yang menang dan siapa yang kalah. Efek lanjutannya adalah kemudian hukum menjadi sandaran bagi kepentingan tertentu dengan pola liberalisasi maupun privatisasi tanpa ada dasar norma moralitas tertinggi seperti yang disebut oleh Hans Kelsen sebagai Grundnorm.

Oleh karena itu, sollen dalam pemahaman normatif adalah sebuah idea-hukum yang bersifat transendental dan normatif, ia adalah akumulasi dari pola pikir dan kearifan yang terbentuk dari pembacaan sosial untuk melahirkan sebuah ide-ide preskriptif hasil dari kontemplasi atas norma dan asas yang berkembang dimasyarakat. Sollen dan sein memang tidaklah selalu paralel, namun keduanya sinergi dalam suatu diskursus teoritik hukum dan tidak bisa dipisahkan karena merupakan dasar reflektif satu sama lain.

Penciptaan hukum harus benar-benar didasarkan pada dasar normatifnya sehingga aktualisasi terhadap sistem norma selaras dan sesuai dengan kebutuhan serta kesadaran sosial. Hukum yang tidak sesuai dengan nilai-nilai dan jiwa sosial harus diragukan legitimasi normatifnya dan bahkan secara empiris legitimasi sosiologisnya. Hukum sesuai dengan hakikatnya sebagai refleksi sosiologis seharusnya tidak mempunyai persoalan dengan efektifitas dan validitasnya.

Perlu ada evaluasi terhadap sistem penormaan atau sistem hukum serta sistem ketatanegaraan Indonesia saat ini. Terutama sebuah konsep yang benarbenar didasarkan pada pemahaman nilai-nilai kultural dan kemasyarakatan saat ini, harus ada distilasi terhadap sisa-sisa pengaruh hukum Asing yang masih digunakan tetapi diragukan efektifitasnya. Untuk itu perlu digiatkan bentuk-bentuk penelitian terhadap nilai-nilai kelokalan dan menggali interrelasi antara sejarah, kebudayaan, serta Adat.

Penggalakan pembelajaran teoritik yang lebih mendalam harus segera digalakkan untuk menciptakan ilmuwan-ilmuwan hukum yang berpola pikir kelokalan. Setiap calon sarjana harus dididik untuk mampu mengembangkan orisinilitas pemikiran sendiri, bukan sebagai ahli membeo yang hanya terus mengulang pola pikir sebelumnya. Pembelajaran metode multidisipliner dan wawasan postmodernis saat ini juga harus dikembangkan, namun harus benarbenar ditekankan bahwa dasar pemikiran normatiflah yang diutamakan. Banyak 
para sarjana cenderung tendensius terjebak di pola pikir empiris daripada normatif karena terpengaruh para pemikir politik, sosiologi ataupun antropologi.

\section{DAFTAR PUSTAKA}

\section{a. Buku}

Amirin, Tatang M. (1989). Pokok-Pokok Teori Sistem. Cet. IV. Jakarta; CV. Rajawali.

Boediarto, M. Ali. (Ed.) (2002). Kapita Selekta Hukum Adat; Suatu Pemikiran Baru Prof. Dr. H. Moh. Koesnoe, S.H. Jakarta: Varia Pengadilan.

Friedman, Lawrence M. (2009). Sistem Hukum Perspektif Ilmu Sosial (Penerjemah: M. Khozim). Bandung: Nusa Media.

Hart, H.L.A. (2009). Konsep Hukum (Penerjemah: M. Khozim). Bandung: Nusa Media.

Hazairin (1974). Tujuh Serangkai Tentang Hukum. Jakarta: Tintamas.

Ihromi, T.0. (Peny.) (1984). Antropologi dan Hukum. Jakarta: Yayasan Obor Indonesia.

Kelsen, Hans (2011). Teori Umum tentang Hukum dan Negara.Penerjemah: Raisuk Muttaqien. Bandung: Nusa Media.

Marzuki, Peter Mahmud (2013). Pengantar Ilmu Hukum. Jakarta: Prenadamedia.

MD, Mahfud (2012). Politik Hukum di Indonesia. Jakarta: Rajawali Press.

Mertokusumo, Sudikno (2011). Kapita Selekta Ilmu Hukum. Yogyakarta: Liberty.

Meuwissen (2007). Tentang Pengembangan Hukum, Ilmu Hukum, Teori Hukum dan Filsafat Hukum. Penerjemah: B. Arief Sidharta. Bandung: Refika Aditama.

Nonet, Philippe dan Selznick, Philip (2015). Hukum Responsif. Penerjemah: Raisul Muttaqien. Bandung: Nusa Media.

Peters, A.A.G. dan Siswosoebroto, Koesriani (Ed.) (1988). Hukum dan Perkembangan Sosial; Buku Teks Sosiologi Hukum. Jakarta: Pustaka Sisnar Harapan.

Rahardjo, Satjipto (2007). Biarkan Hukum Mengalir. Jakarta: Kompas.

Rasjidi, Lili dan Putra, I.B. Wyasa (2003). Hukum sebagai suatu Sistem. Bandung: Mandar Maju.

Sidharta, Bernard Arief (2009). Refleksi Tentang Struktur Ilmu Hukum. Bandung: Mandar Maju.

Soekanto, Soerjono dan Abdullah, Mustafa (1980). Sosiologi Hukum dalam Masyarakat. Jakarta: Rajawali.

Suriasumantri, Jujun S (2010). Filsafat Ilmu: Sebuah Pengantar Populer. Cet. XXII. Jakarta: Putaka Sinar Harapan.

Van Kan, J. dan Beekhuis, J.H (1955). Pengantar Ilmu Hukum (Penerjemah Moh. O. Masdoeki). Djakarta; PT. Pembangunan.

\section{b. Jurnal}

Rampadio, Hamdan (2015) Kesadaran Hukum Masyarakat dalam Penegakan Hukum Tindak Pidana Penyalahgunaan Narkotika di Sulawesi Tengah. Jurnal KIAT Universitas Alkhairaat.

Ruba'I (2015). Kesadaran Hukum Masyarakat dalam Berlalulintas di Kepulauan Meranti. JOM Fakultas Hukum, 2(2). 
Tohir, Toto (2011). Rekonstruksi Budaya Hukum Nasional Yang Berbasis Nilai-Nilai Budaya Hukum bangsa Indonesia. Jurnal Syiar Hukum FH. UNISBA, 8(1).

\section{c. Tesis}

Isidiyanto, Ilham Yuli (2015), Refleksi Dialektis Pancasila sebagai Sistem Hukum dan Ketatanegaraan Indonesia. Unpublished Thesis, Yogyakarta: UII.

\section{d. Internet}

Mahkamah Agung. (2017). Periode Januari-Oktober 2017, 91,16\% Perkara diputus MA Kurang dari 3 bulan. Diunduh melalui https://kepaniteraan.mahkamahagung.go.id/index.php/kegiatan/1543periode-januari-oktober-2017-91-16-perkara-diputus-ma-kurang-dari-3bulan. [Diunduh pada 1 April 2018]

Tim Penyusun Laporan Tahunan KPK 2016. Laporan Tahunan 2016. (2017). Diunduh melalui https://www.kpk.go.id/id/publikasi/laporan-tahunan/ [Diunduh pada 1 April 2018]

Tim Penyusun Laporan Tahunan KPK 2017. Laporan Tahunan 2017. (2018). Diunduh melalui https://www.kpk.go.id/id/publikasi/laporan-tahunan/ [Diunduh pada 1 April 2018] 